\title{
International and Domestic Technology Transfers and Productivity Growth: Firm Level Evidence
}

\author{
René Belderbos \\ Katholieke Universiteit Leuven \\ UNU-MERIT and Universiteit Maastricht \\ Vincent Van Roy \\ Katholieke Universiteit Leuven
}

Florence Duvivier

Université Libre de Bruxelles

Correspondence: Katholieke Universiteit Leuven, Department of Managerial Economics, Strategy and Innovation, Naamsestraat 69, B-3000 Leuven, Belgium; email: rene.belderbos@econ.kuleuven.be, phone-number: +3216326912

\section{Acknowledgements}

This research was conducted with support from the Flemish Research Organization for Entrepreneurship and International Entrepreneurship (STOIO). The paper benefited from helpful comments of two anonymous referees, Bruno Cassiman, Bent Dalum, Pierre Mohnen, Leo Sleuwaegen, Reinhilde Veugelers, and participants at a seminar at the Katholieke Universiteit Leuven, the 2008 DRUID-DIME Winter Conference, the 2009 DRUID summer conference, and the 2009 EARIE conference. The usual disclaimer applies. 


\title{
International and Domestic Technology Transfers and Productivity Growth: Firm Level Evidence
}

\begin{abstract}
We examine the impact of international and domestic technology transfers on firms' productivity performance in a sample of 448 Belgian innovating firms during 2003-2006. Technology transfers may occur through R\&D contracting, purchase of licenses and know how, purchase of specialized machinery, hiring of specialized personnel, and various informal channels. Estimates of a dynamic productivity model show that firms engaging in international knowledge transfer strategies record substantially and significantly higher productivity growth. While we do not find statistical evidence of complementarity between international and domestic transfers, the largest impact on productivity is found if firms combine international and domestic transfer strategies, suggesting that a diverse external technology sourcing strategy combining local know how with know how from abroad is most effective. Such combined domestic and international technology sourcing strategies are associated with firms' basic research orientation, $R \& D$ intensity and the successful use of technology protection strategies to appropriate the benefits of innovation efforts. Foreign multinational firms are more likely to adopt technology transfer strategies solely focusing on international transfers. Multinational firms do not exhibit faster productivity growth if the effects of technology transfers and R\&D are taken into account.
\end{abstract}

Key words: Technology transfer, Productivity, Multinational Firms

JEL classification: F23, O32, O33, D24 


\section{Introduction}

There is widespread consensus that the diffusion of knowledge and technologies is essential for economic growth and prosperity (e.g., Grossman and Helpman, 1991; Romer, 1990). As knowledge flows are not restricted to national boundaries, international knowledge flows have been found to be a major source of productivity growth (Coe and Helpman, 1995; Griffith et al., 2004). Important mechanisms for international knowledge diffusion are international trade (e.g. Coe and Helpman, 1995), international arm's length technology trade and licensing (Basant and Fikkert, 1996; Braga and Wilmore, 1991; Branstetter and Chen, 2006), and foreign direct investment (FDI) by multinational enterprises (MNEs).

In recent work, the role of MNEs has received substantial attention. MNEs investing abroad often introduce superior management skills and advanced technologies developed in their home base (e.g. Caves, 1971; 2007), which serve to establish a competitive advantage in their foreign operations (e.g. Belderbos, Ito, and Wakasugi, 2008). These compensate their potential 'liability of foreignness': disadvantages arising from a lack of familiarity operating in local markets (e.g. Zaheer, 1995; Mezias, 2002). Empirical research has shown that affiliates of foreign MNEs have systematically higher productivity levels (Doms and Jensen, 1998; Bellak and Pfaffermayr, 2002; Bellmann and Jungnickel, 2002; Temouri et al. 2008; Criscuolo and Martin, 2009; Criscuolo et al., 2009), which is attributed to the transfer of superior technologies from abroad. ${ }^{i}$ Whilst technology transfer to and exploitation in foreign affiliates is a key feature of the operations of MNEs, recent studies suggest that multinational firms also establish affiliates abroad to get access to centers of excellence in technology development with the aim to source foreign technology (e.g. Griffith et al. 2006; Driffield et. al, 2010). Several studies, mostly exploiting patent citation data, have found evidence of such 'reverse' intra-firm knowledge transfer from affiliates to the home country (Branstetter, 2006; 
Frost, 2001; Frost and Zhou, 2005; Griffith et al. 2006; Singh 2007; Song and Shin, 2008; Criscuolo, 2009).

A drawback of the extant approaches to the analysis of international technology diffusion and transfer is the lack of direct measurement of knowledge flows and direct evidence of the productivity effects of such technology transfers. ${ }^{\text {ii }}$ Knowledge and technology flows are instead inferred from productivity differences or imperfectly and partially measured through patent citations. While a separate literature on technology 'make' and 'buy' decisions has used a broader definition and direct measure of technology sourcing in the form of external R\&D expenditures (e.g. Bönte, 2003; Cassiman and Veugelers, 2006; 2007; Lokshin et al., 2008; Veugelers and Cassiman, 1999; Vega-Jurado, 2009), it has not examined the international dimension of such transfers. ${ }^{\mathrm{iii}}$

In this paper we aim to fill the gaps observed in prior research. We contribute to the literature on international technology flows and productivity by examining direct evidence on firms' international technology transfers and the consequences for productivity growth. We furthermore broaden the perspective on technology transfers in two ways. First, we do not only examine technology transfers within MNEs but also investigate the role of technology transfer strategies in domestic firms, which may be active in a variety of international knowledge sourcing's strategies as well. Second, we compare the effectiveness of international sourcing strategies with the effects of domestic technology transfers and we examine the potential complementarity between such transfers. Third, we also examine the antedendents of international and domestic technology transfer strategies and investigate to what extent multinational firms exhibit systematically greater propensities to engage in these.

We estimate a dynamic productivity model for a sample of 448 Belgian firms, 20032006. We derive our econometric specification of productivity growth from an augmented Cobb-Douglas production function where changes in the knowledge stock are a function of 
internal and external R\&D and domestic and international technology transfers. The model also takes into account potential productivity convergence over time and potential endogeneity of the technology transfer variables. We employ a broad and direct measure of incoming technology transfers ${ }^{\text {iv }}$, including the transfer of technology through licensing and know how transfer contracts, $R \& D$ contracting, the purchase of specialized machinery, the hiring of specialized personnel, and transfers through informal channels. Prior to examining the performance effects of technology transfer strategies, we examine which characteristics of firms are systematically related to the adoption of the different technology transfer strategies and we examine to what extent there are different propensities to engage in (international) technology transfers by local MNEs and affiliates of foreign MNEs.

The remainder of our paper is structured as follows. The next section briefly reviews the relevant existing literature on knowledge transfers and productivity growth. This is followed by a description of the productivity model in section 3 . The data and empirical methods are described in section 4 and the empirical results in section 5. Finally section 6 offers some concluding remarks and recommendations for future research.

\section{Previous Literature}

Several streams of literature inform our analysis of the productivity effects of domestic and international technology transfer strategies. A first stream of literature focuses on productivity differences between domestic firms and MNEs (e.g. Doms and Jensen, 1998; Bellak and Pfaffermayr, 2002; Bellmann and Jungnickel, 2002; Temouri et al. 2008; Criscuolo and Martin, 2009). These studies examine panel data on firms in various countries, among which the US, Germany, and the UK, to observe a clear pattern. Affiliates of foreign R\&D have a productivity advantage over domestic firms but are not significantly more productive than domestic MNEs. These results are consistence with the notion in the theory of 
the MNE that firms become multinational to exploit superior intangible assets such as managerial skills and technological knowledge (Hymer, 1976). Firms self-select to become an MNE (e.g. Hussinger and Arnold, 2005) because only firms with compensating advantages can deal with the additional costs of setting up abroad and the potential liability of foreignness of operating in foreign countries (Caves, 1971; 2007). Criscuolo et al. (2009) show that multinational firms performance is strongly related to internal cross-border knowledge exchange.

A related literature in the international business domain has examined the liability of foreignness in more detail (Zaheer, 1995, Mezias 2002, Nachum, 2010). Affiliates of multinationals may face disadvantages compared to local firms due to unfamiliarity with the local business environment and lack of embeddedness and legitimacy in the host country, which lead to higher transaction costs and information asymmetries. These studies focus on the importance of practices and technologies transferred by MNEs to their host countries to overcome this liability. In support of the notion that MNEs transfer technology and management skills to remain competitive in foreign markets, DeBacker and Sleuwaegen (2005) confirm that the greater the expected liability of foreigness (related to cultural and geographic distance) the larger the productivity benefit of foreign affiliates at entry.

An alternative approach used in the literature is to trace knowledge flows through citations between patents (Almeida, 1996; Frost, 2001; Jaffe et al., 1993). This approach exploits the notion that existing innovations provide ideas and inspiration for further innovation, such that patent citations are likely to capture part of the knowledge flows across organizations. While the productivity literature has focused on the role of MNEs in enabling technology transfer to host countries, the citation based literature has emphasized that MNEs can use foreign subsidiaries as a means of accessing knowledge in host countries. Frost (2001) and Almeida (1996) found that foreign affiliates tended to be locally embedded and 
citing host country inventors more actively. Singh (2007) obtained similar findings in a larger scale analysis of patent data examining bi-directional knowledge flows between host countries and MNE affiliates. In particular in the United States, foreign MNEs more intensively cite local firms than local firms cite MNEs, providing further evidence that foreign owned affiliates are active in local technology sourcing. These findings are consistent with the finding of Branstetter (2006) that Japanese firms with affiliates in the US have a significantly higher probability of citing other US firms' patents.

Affiliates of foreign MNEs can combine the exploitation of knowledge and technologies obtained from the parent firm with a local knowledge sourcing role (e.g. Driffield et al, 2010). Local knowledge sourcing by foreign affiliates however does not necessarily imply that this knowledge is further diffused in the international R\&D network of the multinational firm. Frost (2001) argues that effective intra-firm knowledge diffusion requires 'dual embeddedness' on the part of the affiliate, i.e. embeddedness in both (local) external and in (international) intra-firm networks, hence the combination of local and international knowledge transfers. Lack of effective integration both in local and intra firm networks may go some way to explain the relatively ambiguous evidence on the effectiveness of reverse technology transfers. In particular acquired firms, while locally embedded, often appear to maintain autonomy without substantial integration into the MNEs R\&D network (Frost, 2001). Gupta and Govindarajan (2000) also suggest that the flows of knowledge from overseas affiliates back to headquarters have remained limited, and propose more intensive use of a variety of (formal and informal) communication networks between headquarters and affiliates to facilitate technology transfers. Frost and Zhou (2005) show that R\&D collaboration between affiliates and the parent firm facilitates subsequent exchange of knowledge. 
A number of recent studies do find qualified evidence for reverse technology transfer. Song and Shin (2008) and Penner-Hahn and Shaver (2005) find that performance effects can occur if corporate headquarters are able to utilize and integrate foreign know how and $R \& D$ results. Iwasa and Odagiri (2004) find that R\&D in US affiliates of Japanese firms have a positive impact on parent firms' patent applications in Japan, provided that R\&D activities are focusing on basic research and that they are located in US states with particular technological strengths in the technology field of interest. Griffith, Harrison \& van Reenen (2006) find that foreign R\&D in the US by UK MNEs has a positive impact on their productivity if $R \& D$ is 'locally embedded' (in the sense that the patents are citing US firms or US institutions) and if the US presence allows firms to benefit from a growing US knowledge stock in the sector. Todo and Shimizutani (2008) similarly find qualified evidence of reverse technology flows associated with technology sourcing R\&D for Japanese firms. Overall, there appears to be emerging evidence that foreign $\mathrm{R} \& \mathrm{D}$ can lead to reverse technology transfer and a positive impacts on the productivity of parent firm operations. ${ }^{\mathrm{v}}$

A final line of research has analysed technology transfers as external technology acquisition strategies, and has focused on the relationship between internal R\&D ('make') and technology acquisition ('buy') strategies (e.g. Arora and Gambardella, 1990; Veugelers and Cassiman, 1999). The combination of external technology sourcing and internal R\&D can allow firms to benefit from research complementarities through involvement in multiple technological trajectories, research directions that cannot be developed simultaneously (at sufficient speed) in-house, and external skills in the exploitation of in-house research activities. Access to complementary research and development activities performed externally, hence, can improve the performance effects of internal R\&D efforts (Bönte, 2003; Cassiman and Veugelers, 2006; Lokshin et al, 2008). Several studies have provided empirical evidence in this regard. Beneito (2006) using a sample of Spanish firms, finds that contracted 
R\&D improves firms' patent application performance only if it is combined with internal R\&D. Vega-Jurado et al. (2009) conclude that acquisition of knowledge embodied in machinery and equipment fosters primarily process innovations. Cassiman and Veugelers (2006) found that (Belgian) firms that combine internal R\&D with technology sourcing strategies show a better innovative performance as measured by the proportion of innovative products in sales. Lokshin et al. (2008) examined the joint impact of internal and external $R \& D$ expenditures on productivity in a 6-year panel of innovative firms in the Netherlands. They found complementary effects of internal and external $R \& D$, with a positive impact of external R\&D only evident in case of sufficient internal R\&D.

In the current paper, we contribute to MNE and productivity as well as the 'make versus buy' literatures, by examining the simultaneous impact of international and domestic technology transfers on productivity growth in a sample of Belgian firms. Compared with the 'make versus buy' literature, we bring in the international dimension of technology acquisition. We contribute to the productivity and MNE literature by investigating the role of technology transfers in productivity advantage and by using direct measures of the actual occurrence of technology transfers. At the same time, we broaden the analysis to include domestic firms as well as foreign affiliates and domestic MNEs.

\section{A Model of Productivity Growth}

In this section we develop a model of technology transfers and productivity growth. We draw on Lokshin et al. (2008) and use an augmented Cobb-Douglas framework, with the knowledge stock considered as a production factor:

$$
Y_{i t}=C_{i t}^{a} L_{i t}^{\beta} K_{i t}^{\gamma} e^{\sigma_{i t}}
$$


where $Y$ is value added of affiliate firm $i$ at time $t, L$ is the labor input, $C$ is the physical capital stock and $K$ is the knowledge stock. $\alpha, \beta$ and $\gamma$ are elasticities with respect to physical capital, labor and the knowledge stock, respectively. The parameter $\sigma$ is a time variant and affiliate-specific efficiency parameter. Dividing both sides by labor, taking the $\log$ and differencing the resulting equation in the two consecutive periods, we obtain the equation in its growth form:

$\Delta q_{i t}=(\beta-1) \Delta l_{i t}+\alpha \Delta c_{i t}+\gamma \Delta k_{i t}+\Delta \sigma_{i t}$

where $\Delta q_{i t}=\log \left(Y_{i t}\right)-\log \left(L_{i t}\right)$ denotes the growth in labor productivity, with lower case letters denoting variables in natural logarithms. In equation (2) fixed firm differences in productivity are eliminated from $\Delta \sigma_{i t}$, but we model the change in firm-specific efficiency levels as a function of past productivity.

$$
\Delta \sigma_{i t}=\theta q_{i t-1}+\varepsilon_{i t}
$$

where $\varepsilon_{i t}$ is a serially uncorrelated error term. This specification allows for gradual convergence in efficiency levels between firms, which has been observed to be important in the empirical productivity literature, with lagging firms able to improve their productivity faster (Blundell and Bond 2000; Klette, 1996; Lokshin et al., 2008; Klette and Johansson, 1998; Hall e al., 2010). We expect $\theta$ to fall within the interval $[-1,0]$. If $\theta$ is zero there is no gradual convergence; if $\theta$ is -1 complete convergence materializes in one period.

We transform the knowledge stock portion of the specification such that it is expressed in changes in the knowledge stock (cf. Jones, 2002, p. 233) as follows: 
$\gamma \Delta k_{i t} \approx \frac{\partial Y}{\partial K} \frac{K_{t-1}}{Y_{t-1}} \frac{\Delta K}{K_{t-1}} \approx \varphi \frac{\Delta K_{i t}}{Y_{t-1}} \quad$ with $\varphi=\frac{\partial Y}{\partial K}$

We take the change in knowledge capital stock as a function of the intramural $R \& D$ investments and international and domestic technology transfers of a firm:

$\Delta K_{i t}=f\left(T_{i t-1}^{\mathrm{int}}, T_{i t-1}^{d o m}, T_{i t-1}^{\mathrm{int}, d o m}, R D_{i t-1}\right)$

where $T_{i t-1}^{d o m}$ denotes domestic transfers, $T_{i t-1}^{\mathrm{int}}$ international transfers and $T_{i t-1}^{\mathrm{int} d o m}$ joint domestic and international transfers. We approximate the unknown function (5) by a linear function. If the depreciation rate of the knowledge stock is small ${ }^{\mathrm{vi}}$ we can write:

$\gamma \Delta k_{i t}=\varphi\left(\eta_{1} T_{i t-1}^{d o m}+\eta_{2} T_{i t-1}^{\mathrm{int}}+\eta_{3} T_{i t-1}^{\mathrm{int}, d o m}+\eta_{4} R D_{i t-1}\right) / Y_{i t-1}$

Combining equations (2), (3), and (6), we arrive at the dynamic equation:

$\Delta q_{i t}=\theta q_{i t-1}+(\beta-1) \Delta l_{i t}+\alpha \Delta c_{i t}+\varphi\left(\eta_{1} T_{i t-1}^{d o m}+\eta_{2} T_{i t-1}^{\mathrm{int}}+\eta_{3} T_{i t-1}^{\mathrm{int}, d o m}+\eta_{4} R D_{i t-1}\right) / Y_{i t-1}+\varepsilon$

Productivity in year $\mathrm{t}$ is a function of past productivity levels, the growth in employment, the augmentation of the capital stock, and the intensity of intramural $R \& D$ expenditures and technology transfer activities. Similar dynamic productivity models have been used in prior literature on R\&D investment and productivity (E.g. Klette, 1996; Lokhin and Mohnen, 2007; Klette and Johannson, 1998; Lokshin et al., 2008) ${ }^{\mathrm{vii}}$. The model has the properties of a partial adjustment models often used in the estimation of capital investment functions (e.g. Abel and 
Aberly, 1994) and allows distinguishing between short-term effects of technology strategies (the estimated coefficients) and long term effects (the coefficients times $1 /(1+\theta)$ ). Technology transfers boosting productivity have long term effects because they provide productivity advantages in future periods as well, and these advantages are only gradually reduced to zero due to productivity convergence.

\section{Data, Variables and Empirical Methods}

The data for our study were drawn from the fourth Community Innovation Survey (CIS) conducted in Belgium. This CIS survey, conducted in 2005, contains information on innovation strategies of firms in manufacturing and service industries for the period 20022004. The survey included a detailed set of questions on technology transfer activities by type of channel, including the national or international origin of the transfers. Unfortunately, the detailed questions on technology transfers have no longer been included in later innovation surveys in Belgium, such that we have to limit the analysis to the results of the $4^{\text {th }}$ survey. Because we do have yearly data on firm productivity, the analysis can take into account appropriate time lags and dynamic productivity specification.

The detailed questionnaire is answered by firms that are innovation active and covers virtually all larger firms and a sample of small and medium size enterprises in Belgium. The data we could access was restricted to firms based in the Flemish region of Belgium, where the large majority of innovation active firms are located. The survey contains information on 878 firms engaged in innovation efforts and/or formal $R \& D$ expenditures. We merged this dataset with yearly corporate accounts data of the firms in order to analyze the impact of $R \& D$ and technology transfers on productivity growth. Due to missing values for a number of variables (e.g. on fixed capital investments in the corporate accounts data, or on technology transfers in the CIS data), our sample was restricted to 448 firms. The distribution of firms 
over industries is roughly similar as the distribution of all firms in the survey and is presented in Table $1 .^{\text {viii }}$ The firms are fairly well distributed over manufacturing industries, with the largest number in the metal products sector, followed by food and drinks, and the electrical equipment industry. Among the service industries, the largest number of firms is in the transport and telecommunication industries, while the financial sector is less well represented.

\section{INSERT TABLE 1}

In the CIS surveys innovative companies are asked to report whether they acquired and transferred technology in the years 2002-2004 through various channels. The channels include the acquisition of technology through licensing and transfer of know how, R\&D contracting, the purchase of specialized machinery, hiring of specialized personnel, and transfers through informal channels. ${ }^{\text {ix }}$ We omit from our definition of technology transfer the channel 'consultants', as firms are likely to tick this question also in case of more general consultancy services contracted (e.g. Cassiman and Veugelers, 2007). Similarly the channel 'acquisition of other firms' is omitted as it is seldom reported and since takeovers may often be associated with a variety of other impacts on productivity (e.g. through rationalization efforts, or post-acquisition integration difficulties) than through technology transfer.

The $4^{\text {th }}$ CIS survey also asks firms to indicate from which location the technology transfer occurred: from inside Belgium or from abroad. We combined the information on these five channels of transfers considered and the information on the origin of these transfers to construct three exclusive dummy variables. The variable domestic technology transfer takes the value 1 if a firm reported to have been active in one or more channels of transfers, while the origin of these technologies was restricted to Belgium. The variable international technology transfer takes the value 1 if a firm reported to have been active in one or more 
channels of transfers, but the origin of these technologies was invariably abroad. The variable domestic \& international technology transfer takes the value 1 if the firm transferred technology from within Belgium as well as from abroad. ${ }^{\mathrm{x}}$ While there is information on the total amount spent on these technology transfer activities, this amount is not further divided over the domestic and international sources of the transfers. This implies that the productivity equation to be estimated has to be adapted from equation (7).

\section{Productivity Analysis}

To investigate the impact of technology transfer strategies on productivity, we estimate an adapted equation based on equation (7). Instead of three technology transfer intensity variables, we include the three technology transfer dummies in combination with the intensity of overall technology acquisition activities (the value of expenditures on technology acquisition divided by value added). We empirically estimate equation (8):

$$
\begin{array}{r}
\Delta q_{i t}=\theta q_{i t-1}+(\beta-1) \Delta l_{i t}+\alpha \Delta c_{i t}+\varphi\left(\eta_{1} T d_{i t-1}^{d o m}+\eta_{2} T d_{i t-1}^{\mathrm{int}}+\eta_{3} T d_{i t-1}^{\mathrm{int}, d o m}\right)+ \\
\phi\left(\eta_{4} R D_{i t-1}+\eta_{5} R D_{i t-1}^{a c q}\right) / Y_{i t-1}+\varepsilon
\end{array}
$$

where $R D_{i t-1}^{a c q}$ is total expenditure on technology acquisition, $R D_{i t-1}$ is intramural $\mathrm{R} \& \mathrm{D}$ expenditure, and $T d$ are the technology transfer dummy variables. ${ }^{\mathrm{xi}}$ The dependent variable in the productivity analysis, growth in labor productivity, is measured as the difference in the $\log$ value added per employee in 2006 and the log value added per employee in 2003. We took a three-year period to examine productivity growth, as the impact of firms' innovation strategies on performance may be more gradual, and because we are interested in sustained performance differences. The period includes productivity growth during 2003-2004 because the core variables of interest, technology transfers, are measured over the years 2002-2004 
and may have their impact before 2004-2005. By including growth during 2003-2004, we want to limit the possibility that the effect of technology transfers is already largely captured in existing productivity levels. Lagged productivity $\left(q_{i t-1}\right)$ is the $\log$ of value added per employee in 2003. Equation (8) further suggests inclusion of the growth in fixed assets $\left(\Delta c_{i t}\right)$, the $\log$ difference in the value of fixed assets between 2003 and 2006, and the growth in employment $\left(\Delta l_{i t}\right)$, measured in the same manner. We control for price increases by using industry specific deflators from Eurostat for value added and fixed capital. We augment the equation by including two dummy variables to control for firm internationalization: domestic multinational firm and (affiliate of) foreign multinational firm. These are identified by questions in the CIS survey concerning the ownership of the firms' equity and the presence and control of foreign affiliates. Finally, we include a set of 17 2-digit industry dummies, with the wholesale and retail trade industry as the reference industry, to control for industry differences in productivity dynamics.

\section{Technology Transfer Strategy Adoption}

Before we estimate the productivity model, we examine which characteristics of firms are associated with the adoption of the three technology transfer strategies. The aim is to understand more about the underlying drivers of technology sourcing strategies. The results can also inform us about suitable instruments differentiating firms adopting the various strategies, which can be used as inputs for an instrumental variable analysis of the impact of technology transfer strategies on productivity. We use a multinomial probit model to relate the probability that firms choose a specific transfer strategy or no transfer strategy to a set of firm characteristics, taking the case of no technology acquisition as reference choice. Given the cross section nature of the analysis and the difficulty of instrumenting for potentially endogenous firm variables, we treat the results as associations rather than causal effects. 
Turning to firm characteristics that are likely to be relevant for the technology transfer strategies, we expect that firms with an export orientation are more likely to explore and get access to international sources of knowledge. They may also have a greater need to use international technologies in order to adapt products to foreign markets and to learn by exporting (e.g. Clerides et al, 1998). We include the dummy export, indicating whether the firm was engaged in exports in the year 2002 and expect a positive association with technology acquisition strategies including technology transfer from abroad.

Following the absorptive capacity argument (Cohen and Levinthal, 1989) we expect that firms that are more active in $R \& D$ are also more likely to engage in technology sourcing strategies (Cassiman and Veugelers, 2006). Internal R\&D capabilities are likely to increase the effective utilization of external know how (Arora and Gambardella, 1990). We include the $\log$ of firms' intramural R\&D expenditures. In addition, firms with a greater orientation towards basic research in their $\mathrm{R} \& \mathrm{D}$ activities may possess greater capabilities in combining technologies from different sources, with a greater likelihood of complementarities between in-house R\&D and technology sourcing. Following Cassiman and Veugelers (2007), we include as the indicator of basic $R \& D$ orientation, the importance of universities and research centers as an information source for the innovation process, relative to the importance of other sources of information.

Obstacles to in-house innovation may be a driver of external technology sourcing (Bönte, 2003; Cassiman and Veugelers, 2006). A lack of organizational resources to complete in-house $R \& D$ projects may provide the motivation to source technologies externally (Cassiman and Veugelers, 2007). We include the variable resource limitations, the importance of a lack of technical personnel and financial resources as an obstacle to innovation as measured on a scale of 0 (not important) to 9 (very important). We also expect that the effectiveness of protection strategies to appropriate the benefits from innovation 
activities increases the incentives to invest in external technology acquisitions and $R \& D$ activities in general (Belderbos et al. 2008c; Cassiman and Veugelers, 2007; Cohen et al, 2003). We include as a measure of the effectiveness of technology and innovation protection strategies, technology protection, the sum of values (ranging from 0-12) on the importance of the various means to protect technologies (secrecy, lead time, complexity, and patents). ${ }^{\text {ii }}$

We also examine whether, after controlling for the above factors, domestic MNEs and affiliates of foreign MNEs are more likely to adopt specific technology sourcing strategies. Domestic MNEs may have the possibility to engage in international technology sourcing, while affiliates of foreign MNEs can rely on parent technologies or access to the broader network of the parent to source international technologies. Hence we include the dummy variables domestic multinational firm and (affiliate of) a foreign multinational firm. Finally, we also include a set of industry dummies to control for industry wide differences in technology sourcing strategies, e.g. as related to the maturity of the technologies used in the industry. ${ }^{\text {xii }}$

\section{Descriptive Statistics}

Table 2 presents the means and standard deviation of the variables as well the variable definitions. Correlations between the variables are given in Appendix A. Table 2 shows that the average three-year labor productivity growth for the firms in the sample is 12.1 percent. Employment and fixed asset growth has been negative on average. ${ }^{\text {xiv }}$ The majority of firms are domestic with no international operations, while Belgian multinationals and foreign affiliates make up 10.3 and 31 percent of the sample, respectively. The majority of firms had acquired technology externally, close to 46 percent both of domestic and international origin, close to 14 percent of international origin only, and 25 percent only of domestic origin. About 15 percent of firms did not engage in any acquisition of technology. 


\section{INSERT TABLE 2}

Further insights are obtained when we differentiate means and standard deviations by type of technology transfer (table 3). Table 3 shows that firms engaged in both domestic and international technology transfer record the highest productivity growth (14.7 percent), closely followed by firms with international transfers only (12.6 percent) and firms with domestic transfers only (12.7 percent), while there is an important gap with firms not engaged in technology acquisition (2.8 percent). Foreign multinational firms are best represented among the group of firms engaged in international sourcing strategies (50 percent), followed by joint sourcing strategies (40.1 percent). A substantial share of firms adopting international or joint sourcing strategies were exporting in 2002 (respectively, 95 and 93 percent) while the presence of exporting firms among firms with no or only domestic transfers is less pronounced (74 and 81 percent). Firms with both domestic and international transfers are clearly distinguishable in terms of their size, high basic R\&D reliance, R\&D intensity, and use of technology protection mechanisms. Resource limitations are associated with technology sourcing strategies including domestic sources.

\section{INSERT TABLE 3}

\section{Empirical Results}

We first present the results of the multinomial probit model relating the choice of the different technology sourcing strategies to the set of firm characteristics, with firms reporting no technology transfers as the benchmark case ${ }^{\mathrm{xv}}$. As expected, firms that were engaged in export activities in 2002 are more likely to adopt foreign technology sourcing strategies, 
either in isolation or in combination with domestic technology acquisition. Affiliates of foreign multinationals are significantly more likely to use international-only sourcing strategies, while there is strong evidence that foreign MNEs are less likely to only rely on domestic technology acquisition. Perhaps surprisingly, domestic multinationals are not more likely to use any specific type of sourcing strategies, once we control for other firm characteristics (we return to this issue in the supplementary analyses). The coefficients of the other variables demonstrate that firms adopting joint sourcing strategies show the strongest differences compared with firms that are not engaged in technology sourcing. R\&D intensity, basic $R \& D$ orientation, resource limitations and technology protection are all characteristics associated with joint sourcing strategies. They reflect greater absorptive capacity and broader scope of innovative activities, greater need to access other technology sources and greater returns expected on technology investments in general. Domestic technology acquisition is also associated with resource limitations for in-house $R \& D$ and a more basic $R \& D$ orientation, although to a lesser extent than in the case of joint sourcing strategies. International-only technology acquisition strategies are mostly driven by the engagement in export, basic R\&D orientation and the effectiveness of technology protection. Apart from a propensity to choose for combined sourcing strategies in the textile and leather sector, there appear no significant differences across industries in technology acquisition.

\section{INSERT TABLE 4}

Before estimating equation (8) we tested for potential endogeneity of the technology acquisition strategies, which would render ordinary least squares estimates inconsistent. We employed a Wu-Hausman test (Wooldridge, 2001), which compares the coefficient estimates of the OLS estimates with the estimates of a model in which the potentially endogenous 
variables are instrumented. We selected instruments from the adoption model that were most effective in differentiating between the adoption of the three strategies. To alleviate concerns that these instruments may still be potentially endogenous, we also used variables measuring the sectoral occurrence of transfer strategies as instruments. Industry adoption patterns will be strongly associated with firm-level technology acquisition strategies, but are unlikely to be correlated with firm-specific differences in productivity growth. The sectoral occurrence intensity of only domestic (international, joint) technology transfers is defined as the proportion of firms in a sector that choose an only domestic (only international, joint) technology sourcing strategy. We use the sectoral adoption variable as the instrument for domestic transfer strategies. For international transfer strategies we use the sectoral adoption variable in addition to a dummy variable indicating whether a firm was engaging in export activities in the past (2002). Basic R\&D orientation is used as the instrument for the joint sourcing strategies.

We first conducted an underidentification test, which can verify whether the instruments are relevant, meaning they are sufficiently correlated with the endogenous regressors. The Kleibergen-Paap rk LM statistic robust to heteroskedasticity reported a value of 7.92 with a corresponding $\mathrm{p}$ value for the chi-square test of 0.019 , which rejected the null hypothesis of underidentification of the instruments (Kleibergen and Paap, 2006). The Hansen $\mathrm{J}$ test for overidentifying restrictions was insignificant (p-value of 0.346 ), suggesting that our set of instruments was valid. Finally, the Wu-Hausman test did not reject the null hypothesis that the ordinary least squared estimates of the original productivity model are identical to the estimates of the model with instrumented variables (a p-value of 0.13 ). Other instrument sets that satisfied the Hansen and Kleibergen-Paap tests gave similar insignificant results on endogeneity. We concluded that the technology transfer strategy variables can be regarded as weakly exogenous and that the OLS estimations are consistent. 
The empirical results for the augmented version of equation (8) are presented in table 5. The results in the first column are obtained with ordinary least squares regression with robust standard errors. The estimated coefficient on past labor productivity shows a convergence parameter $\theta$ of -0.258 , suggesting that a little more than a fourth of a productivity lead is neutralized by the next period. The growth of employment and capital stock are significant (at the 1 percent level) and imply an elasticity of 0.67 (1-0.33) for labor and 0.072 for fixed capital. ${ }^{\mathrm{xvi}}$ Intramural R\&D and technology acquisition expenditures have the expected positive effect on productivity growth and are significant. The coefficients of respectively 0.182 and 0.069 approximate the marginal return on these types of $R \& D$ expenditures; they are somewhat lower than those found in earlier studies. ${ }^{\text {xii }}$ All three technology transfer dummies have positive coefficients, but only the dummies for international and joint technology sourcing strategies are significant. Hence, only firms that source technology from abroad, either in isolation or in combination with local technology acquisition, show significantly greater productivity growth. This gain in productivity growth is 10 percent points for international transfers, while joint technology acquisition strategies have the largest impact on productivity growth (13.6 percent points). These are short term effects; the dynamic productivity model would suggest that the long term effects, given that a productivity advantage is only slowly reduced, are about 4 times $((1 /(1-0,258))$ as large. Also, the full short term effects of these strategies may be even larger, as we also have to take into account the impact of the magnitude of overall spending on technology acquisition, part of which is directed to the three transfer strategies. Depending on the intensity of technology acquisition, this may add up to a maximum of 3 percent points in the short term. While the coefficient for joint sourcing strategies is largest, the empirical results do not support the stronger notion that there is complementarity between domestic and international technology 
sourcing strategies. Statistical tests show that the marginal impact of one of these strategies is not significantly increased for firms that adopt the other strategy as well.

After controlling for capital, employment growth, R\&D intensity and technology transfer strategies, foreign and domestic MNE do not show significant differences in productivity growth compared with domestic firms. Hence, any productivity growth advantages of foreign MNEs appear to primarily stem from a more intensive use of international technology transfer strategies.

In an extension of the analysis, we examined whether the results are affected by possible sample selection bias because the analysis is restricted to firms that are innovating and for which information on technology sourcing strategies is available. To address the issue of potentially biased estimates due to the non-randomness of our sample, we estimate a Heckman two-step model. In the first stage of the model we include a number of firm characteristics that increase the probability that the firm is selected into the productivity model. As larger or more mature firms may have a higher propensity to engage into innovative activities, we include firm size and age and their quadratic terms. We also include an indicator of a major reason not to engage in innovation activities, i.e. whether there is insufficient demand for innovative products and services. The importance of lack of demand is measured on a scale of 0 to 3. Finally, we include dummies for foreign and domestic MNEs and a set of industry dummies. The results of the probit model of first stage analysis are relegated to Appendix B. They suggest a positive influence of multinationality and size, while perceived lack of demand for innovation reduces the probability to engage in innovation and hence of inclusion the sample. The results of the second stage of the Heckman model are presented in last columns of Table 5. The estimated coefficients are quite close to the coefficient estimated with the OLS model, indicating consistency of the OLS estimates. In the Heckman model, the estimated coefficients on the technology transfer strategy dummies even 
increase in magnitude by a factor of $10-15$ percent. The consistency of OLS estimates is confirmed by the insignificance of Heckman's rho, which implies that the null hypothesis that the correlation between the error terms of the first and second stage regressions of the Heckman procedure equals zero cannot be rejected.

\section{INSERT TABLE 5}

\section{Supplementary Analysis}

In supplementary analysis we estimated a number of alternative specifications. First, we investigated why domestic multinational firms were not found more likely to adopt technology sourcing strategies or to record higher productivity growth compared to domestic firms. One possible explanation is that this group of multinationals is too heterogeneous and includes firms with only a limited foreign presence (e.g. distribution or service affiliates) which is less likely to be instrumental in increasing international technology transfers. At the same time, one has to note that the coefficient for domestic multinationals in the models measures the impact on technology transfer and productivity beyond the variables already included in the model. Further analysis confirmed that domestic multinationals on average do adopt joint technology strategies more frequently than their peers in the industry in which they are operating. We examined this by estimating a restricted multinomial probit model with the variables limited to a set of industry dummies and the two dummies for foreign and domestic multinational firms. The results showed that both foreign and domestic multinationality increase the probability of joint transfer strategy adoption significantly, with the coefficient for domestic multinationals larger than the coefficient for foreign

multinationals. Hence, in the results reported in table 4, the adoption of joint sourcing strategies by domestic multinationals is driven by the correlated characteristics of these 
multinationals, such as a higher R\&D intensity. ${ }^{\text {xiii }}$ Joint sourcing strategies and R\&D intensity subsequently drive their productivity performance.

Second, we further investigated potential differential effects of international technology transfers depending on the origin of the technology. The survey makes a distinction between European and non-European origin. Examining this property learns that close to 75 percent of incidences of international technology transfer relate to European transfers only, while this is 60 percent for international transfers involving joint sourcing strategies. In order to assess a potentially stronger impact of technology transfers from outside Europe on a firms' productivity growth, we included a dummy variable to the base model indicating whether a firm acquired technology from outside Europe. This dummy variable was insignificant while the parameter estimates of the original transfer dummies did not change materially. The consequences of European vs. non-European origin of technology acquisition may not be straightforward because the distinction is still not sufficiently finegrained. Transfers from outside Europe may include technologically advanced countries (Japan and the US) but may also include less technologically advanced countries. Similarly, technology acquisition from within Europe can include sourcing from countries with various distances from the technology frontier. Further research should aim to examine the effects of the origins of the acquired technologies in more detail. This will require detailed information on the countries of origin of the technologies, combined with information on the technological strength of these countries.

\section{Conclusions}

In this paper we examined the impact of both domestic and international technology transfers on the productivity growth in a sample of 448 Belgian innovating firms during 20032006. Such technology transfers may occur through R\&D contracting, purchase of licenses 
and know how, purchase of specialized machinery, hiring of specialized personnel, and various informal channels. Estimates of a dynamic productivity model show that only firms that are engaged in international technology sourcing, either in isolation or in combination with local technology acquisition, record significantly higher productivity growth. The largest effects are evident for joint domestic and international sourcing strategies, although the empirical results did not support the notion of complementarity between these strategies. Estimates of the (short-run) effects of joint technology sourcing range between a 14 and 16 percent increase in 3-year labor productivity, suggesting a substantial performance impact. These results were robust to tests for sample selection and endogeneity.

These results suggest that diversity in knowledge sourcing has an important role to play in firm productivity dynamics in general: a more diverse, national as well as international, reach of technology sourcing strategies is most likely to be beneficial. This indicates that policies to stimulate innovation should pay close attention to the facilitation of technology acquisition, with in particular international technology acquisition an important factor in the performance effects of technological efforts.

Our analysis of the firm characteristics associated with the various technology sourcing strategies showed that combined domestic and international technology sourcing strategies are more likely to be adopted by firms that face resource limitations in their innovative effort, have a basic research orientation and conduct more $\mathrm{R} \& \mathrm{D}$, and successfully use various technology protection strategies to appropriate the benefits of innovation efforts. The major distinctive drivers of international-only technology transfer strategies are export orientation and the effectiveness of technology protection mechanisms. After taking these factors into account, affiliates of foreign multinational firms are still more likely to engage in technology transfers involving international sourcing only, but domestic multinational firms do not differ from other firms in the propensity to engage in technology transfer strategies. 
Further analysis revealed that domestic multinational firms do adopt joint and international sourcing strategies much more frequently than purely domestic firms, but that the greater intensity of international sourcing is explained by factors such as the higher R\&D intensity and basic R\&D orientation of these multinational firms. In this regard, our results are consistent with the premise that firms 'self select' into multinationality as they seek to exploit their intangible assets abroad (e.g. Hussinger and Arnold, 2005; Caves, 2007), such that multinationality is to an important extent the consequence, rather than the cause, of productivity advantages.

Our results are suggestive that one of the ways in which foreign multinational firms are able to record higher productivity growth is through a greater use of international technology sourcing strategies. This is consistent with the idea that foreign MNEs can draw on technologies developed by their parent firms and in addition have access to a wider range of channels of transfers through the international presence of these parents. It is also in line with the stylized facts on productivity differentials between domestic firms and multinationals (Doms and Jensen, 1998; Bellak and Pfaffermayr, 2002; Bellmann and Jungnickel, 2002; Temouri et al. 2008; Criscuolo and Martin, 2009; Criscuolo et al., 2009). What our results suggest is that foreign affiliates generally are more likely to rely on international-only technology sourcing strategies and could potentially benefit from greater involvement in local technology sourcing. The greater effect on productivity of joint domestic and foreign technology sourcing strategies, are consistent with the 'double embeddedness' argument of Frost (2001) which holds that firms should use local technologies as well as technology available through their parent networks in order to reach their full innovative potential. The relative lack of strategies combining domestic and foreign sourcing strategies may be related to a more difficult access to local sources of knowledge due to a lack of embeddedness in local networks - an aspect of the 'liability of foreignness' of multinational firms operating 
abroad (Zaheer, 1995, Mezias 2002, Nachum, 2010). Analyzing local sourcing strategies by multinational firms abroad would be an interesting subject for future research.

Our results are consistent with the results reported in Criscuolo et al. (2009) on UK innovating firms. If we take into account $R \& D$ expenditures and the intensity of knowledge transfers in affiliates of multinational firms, there is little difference in productivity (growth) left between these firms and purely domestic firms. While Criscuolo et al. (2009) find that MNEs generally use broader means of knowledge sourcing - in terms of combining knowledge from different sources (suppliers, clients, competitors and universities) - we find no evidence of broader knowledge sourcing strategies in terms of combining domestic and international technologies -after we control for other shared characteristics such the R\&D intensity of the firms. This applied a fortiori to domestic multinational firms.

Our research was subject to a number of limitations, which may also suggest directions for future research. First, we note that we could not determine the precise magnitude of the effect of technology acquisition, as data on the value represented by the different technology transfer strategies was lacking. Second, we lacked details on the origin of the technology transfers and the degree to which intra-firm transfers were important. An interesting avenue for future research would be to examine differential effects of international technology transfers depending on their geographic origin and the internal or external dimension, in relation to the closeness of these countries of origin to the technology frontier. Third, it is possible that omitted factors such as organizational capabilities are correlated with the technology acquisition variables, such that the measured effects of technology acquisition are partially biased. Fourth, our analysis was restricted to productivity growth in a cross section of Belgian firms. Future research could also examine to what extent these results hold among populations of firms in other countries and to what extent results are robust to the use of panel data. In order to achieve this, we recommend that innovation surveys should examine 
technology acquisition strategies and their international dimensions on a more systematic basis.

\section{References}

Abel, A.B. and J.C. Eberly (1994), A Unified Model of Investment under Uncertainty, American Economic Review 84, 1369-1384.

Almeida, P. (1996), 'Knowledge sourcing by foreign multinationals: patent citation analysis in the US semiconductor industry', Strategic Management Journal, 17, 155-165.

Arnold, J.M., \& Hussinger, K. (2005). Export behavior and firm productivity in German manufacturing: a firm-level analysis. Review of World Economics, 141(2), 219-243.

Arora, A. and A. Gambardella (1990), 'Complementarity and external linkages: the strategies of the large firms in biotechnology', Journal of Industrial Economics, 38, 361-379.

Basant, R. and B. Fikkert (1996), 'The effects of R\&D, foreign technology purchase, and domestic and international spillovers on productivity in Indian firms', Review of Economics \& Statistics, 78, 187-199.

Belderbos, R., B. Ito and R. Wakasugi (2008), 'Intra-firm technology transfer and R\&D in foreign Affiliates: substitutes or complements? Evidence from Japanese multinational firms', Journal of the Japanese and International Economies, 22, 310-319.

Belderbos, R., K. Fukao and T. Iwasa (2009), 'Domestic and foreign R\&D investment', Journal of the Economics of Innovation and New Technologies, 18, 369-380.

Belderbos, R., M. Carree and B. Lokshin (2004), 'Cooperative R\&D and firm performance', Research Policy, 33, 1477-1492.

Bellak, C., and M. Pfaffermayr (2002), Why Foreign-Owned Firms Are Different: A Conceptual Framework and Empirical Evidence for Austria, in Jungnickel R. (ed.), Foreign-Owned Firms: Are They Different? Basingstoke: Palgrave.

Bellmann, L., and R Jungnickel (2002). Why Do Foreign-Owned Firms in Germany Achieve Above-Average Productivity?, in Jungnickel R. (ed.), Foreign-Owned Firms: Are They Different? Basingstoke: Palgrave.

Beneito, P. (2006), 'The innovative performance of in-house and contracted R\&D in terms of patents and utility models', Research Policy, 35, 502-517. 
Blalock, G. and P.J. Gertler (2008), 'Welfare gains from foreign direct investment through technology transfer to local suppliers', Journal of International Economics, 74, 402421.

Blundell, R. and S. Bond (2000), 'GMM estimation with persistent panel data: an application to production functions', Econometrics Reviews, 19, 321-340.

Bönte, W. (2003), 'R\&D and productivity: internal vs. external R\&D - evidence from West German manufacturing industries', Economics of Innovation and New Technology, 12, 343-360.

Braga, W. and L. Wilmore (1991), 'Technological imports and technological effort: An analysis of their determinants in Brazilian firms', The Journal of Industrial Economics, $39,421-432$.

Branstetter, L.G. (2006), 'Is foreign direct investment a channel of knowledge spillovers: Evidence from Japan's FDI in the United States', Journal of International economics, 8, 325-344.

Branstetter, L.G. and J. Chen (2006), 'The impact of technology transfer and R\&D on productivity growth in Taiwanese industry: microeconometric Analysis using plant and firm-level data', Journal of the Japanese and International Economies, 20, 177-192.

Cassiman, B. and R. Veugelers (2002), 'R\&D cooperation and spillovers: some empirical evidence from Belgium', American Economic Review, 92, 1169-1184.

Cassiman, B. and R. Veugelers (2006), 'In search of complementarity in innovation strategy: Internal $\mathrm{R} \& \mathrm{D}$, cooperation in $\mathrm{R} \& \mathrm{D}$ and external technology acquisition', Management Science, 52, 68-82.

Cassiman, B. and, R. Veugelers (2007), 'Are external technology sourcing strategies substitutes or complements? The case of embodied versus disembodied technology acquisition', IESE Research Papers D/672.

Caves, R. E. (1971), 'International Corporations: The Industrial Economics of Foreign Investment', Economica 38, 1-27.

Caves, R.E. (2007), Multinational Enterprise and Economic Analysis, Cambridge University Press; Cambridge, MA.

Clerides, S., S. Lach and J.R. Tybout (1998), 'Is Learning By Exporting Important? MicroDynamic Evidence From Colombia, Mexico, And Morocco', The Quarterly Journal of Economics, 113, 903-947.

Coe, D. and E. Helpman (1995), 'International R\&D spillovers', European Economic Review, $39(5), 859-887$. 
Cohen, W. and D. Levinthal (1989), 'Innovation and learning: two faces of R\&D', Economic Journal, 99, 569-596.

Cohen, W., et al. (2003), 'R\&D spillovers, patents, and incentives to innovate in Japan and the United States', Research Policy, 31, 1349-1358.

Crespi, G., C. Criscuolo, J. Haskel and M. Slaughter (2007), Productivity growth, knowledge flows and spillovers, CEP Discussion Paper No. 0785, London.

Criscuolo, C. and R. Martin (2009) 'Multinationals and U.S. Productivity Leadership: Evidence from Great Britain', Review of Economics and Statistics, 91, 263-281

Criscuolo, C., J.E. Haskel and J. M. Slaughter (2009), Global engagement and the innovation activities of firms, International Journal of Industrial Organization 28 (2010) 191-202.

Criscuolo, P. (2009), 'Inter-firm reverse technology transfer: the home country effect of R\&D internationalization', Industrial and Corporate Change, 18, 869-899.

De Backer K. Sleuwaegen L. (2005), A closer look at the productivity advantage of foreign affiliates. International Journal of the Economics of Business. 12 (1): 17 -34.

Delgado, M., J.C. Fariñas and S. Ruano (2002), 'Firms' productivity and the export market', Journal of International Economics, 57, 397-422.

Doms, M. and J. Jensen (1998). 'Comparing wages, skills, and productivity between domestic and foreign owned manufacturing establishments in the United States', in: Baldwin, R., Lipsey, R., Richardson, J. (eds.), Geography and Ownership as Bases for Economic Accounting. University of Chicago Press.

Driffield, N., Love, J. H., \& Menghinello, S. (2010). The Multinational Enterprise as a Source of International Knowledge Flows: Direct Evidence from Italy. Journal of International Business Studies, 41, 350-359.

Frost, T.S. (2001), 'The geographic sources of foreign subsidiaries' innovations', Strategic Management Journal, 22, 101-123.

Frost, T.S. and C., Zhou (2005), 'R\&D co-practice and 'reverse' knowledge integration in multinational firms', Journal of International Business Studies, 36, 676-687.

Görg, H. and E. Strobl (2001), 'Multinational companies and productivity spillovers: A metaanalysis', Economic Journal, 111, 723-739.

Griffith, R., R. Harrison and J. Van Reenen (2006), 'How special is the special relationship? Using the impact of US R\&D spillovers on UK firms as a test of technology sourcing', American Economic Review, 96, 1859-1875. 
Griffith, R., S. Redding and J. Van Reenen (2004), 'Mapping the two faces of R\&D: productivity growth in a panel of OECD Industries', Review of Economics and Statistics, 86, 883-895.

Grossman, G.M. and, E. Helpman (1991), 'Endogenous product cycles', The Economic Journal, 101, 1214-1229.

Gupta, A.K. and V. Govindarajan (2000), 'Knowledge flows within multinational corporations', Strategic Management Journal, 21, 473-496.

Hall, B., J. Mairesse \& P. Mohnen (2010), Measuring the Returns to R\&D, in: Hall, B. and Rosenberg, N. , Handbook of the Economics of Innovation, Elsevier, Amsterdam, pp. 10341076.

Haskel, J., Pereira, S., \& Slaughter, M. (2007). Does Inward Foreign Investment Boost the Productivity of Domestic Firms? The Review of Economics and Statistics, 89(3), 482496.

Iwasa, T. and H. Odagiri (2004), 'Overseas R\&D, knowledge sourcing, and patenting: an empirical study of Japanese R\&D investment in the US', Research Policy, 33, 807-828.

Jaffe, A., M. Trajtenberg and R. Henderson (1993), 'Geographic location of knowledge spillovers as evidenced by patent citations', Quarterly Journal of Economics, 63, 577598.

Jones, C. (2002), 'Sources of U.S. economic growth in a world of ideas', American Economic Review, 92, 220-239.

Kleibergen, F. and R. Paap (2006), 'Generalized Reduced Rank Tests Using the Singular Value Decomposition', Journal of Econometrics, 133, 97-126.

Klette, T. J. (1996) R\&D, scope economics, and plant performance, Rand Journal of Economics 27, 502-522.

Klette, Tor Jacob, and Frode Johansen, 1998, Accumulation of R\&D capital and dynamic firm performance: a not-so-fixed effect model. Annales d'Économie et de Statistique, 49/50, 389-419.

Konings, Jozef \& Vanormelingen, Stijn, 2009. "The Impact of Training on Productivity and Wages: Firm Level Evidence,"CEPR Discussion Papers 7473, C.E.P.R., London.

Kugler, M. (2006), 'Spillovers from foreign direct investment: within or between industries?', Journal of Development Economics, 80, 444-477.

Lokshin, B. and P. Mohnen (2007), "Measuring the effectiveness of R\&D tax credits in the Netherlands", UNU-MERIT working paper \#2007-025. 
Lokshin, B., R. Belderbos and M. Carree (2008), 'The productivity effects of internal and external R\&D: evidence from a dynamic panel data model', Oxford Bulletin of Economics and Statistics, 70, 399-413.

Mezias, J. (2002). Identifying liabilities of foreignness and strategies to minimize their effects: The case of labor judgments in the United States. Strategic Management Journal, 23, 229-344.

Penner-Hahn, J. and M., Shaver (2005), 'Does international research and development increase patent output? An analysis of Japanese pharmaceutical firms', Strategic Management Journal, 26, 121-140.

Romer, P.M. (1990), 'Endogenous technological change', Journal of Political Economy, 98, 71-102.

Singh, J. (2007), 'Asymmetry of knowledge spillovers between MNCs and host country firms', Journal of International Business Studies, 38, 764-786.

Song, J. and J. Shin (2008), 'The paradox of technological capabilities: What determines knowledge sourcing from overseas R\&D operations?', Journal of International Business Studies, 39, 291-303.

Temouri, Y., N. Driffield, and D. Anon Higon (2008). 'Analysis of productivity differences among foreign and domestic firms: evidence from Germany', Review of World Economics, 144, 32-54.

Todo, Y., \& Shimizutani, S. (2008). Overseas R\&D activities and home productivity:

Evidence form Japanese firm-level data. The Journal of Industrial Economics, 56(4), $752-777$.

Van Pottelsberghe, B. and F. Lichtenberg (2001), 'Does FDI transfer technology across borders?', Review of Economics and Statistics, 83, 490-487.

Vega-Jurado, J., A. Gutiérrez-Gracia and I. Fernández-de-Lucio (2009), ‘Does external knowledge sourcing matter for innovation? Evidence from the Spanish manufacturing industry', Industrial and Corporate Change, 18, 637-670.

Veugelers, R. and B. Cassiman (1999), 'Make and buy in innovation strategies: evidence from Belgian manufacturing firms', Research Policy, 28, 63-80.

Veugelers, R. and B. Cassiman (2004), 'Foreign subsidiaries as channel of international technology diffusion: some direct firm level evidence from Belgium', European Economic Review, 48, 455-476.

Wooldridge, J. (2001), 'Econometric Analysis of Cross Section and Panel Data', MIT Press, London. 
Zaheer S. (1995). Overcoming the liability of foreignness. Academy of Management Journal 38, 341-363. 
Table 1: Distribution of firms across industries

\begin{tabular}{lr}
\hline \multicolumn{1}{c}{ Industry } & \# Firms \\
\hline Food, drink and tobacco & 38 \\
Textiles and leather & 28 \\
Paper, printing and publishing & 24 \\
Petroleum, chemicals and pharmaceutical & 26 \\
Rubber and plastic & 16 \\
Non-metal mineral products & 14 \\
Metals & 42 \\
Machinery & 32 \\
Electrical equipment & 36 \\
Cars and transport equipment & 16 \\
Other manufacturing industries & 8 \\
Utilities and construction & 12 \\
Retail and wholesale trade & 57 \\
Transportation and telecommunication services & 19 \\
Financial services & 348 \\
IT services & 35 \\
Technical services & 12 \\
Health and social services & 30 \\
\hline Total & 34 \\
\hline
\end{tabular}


Table 2: Description of variables, means, and standard deviations

\begin{tabular}{|c|c|c|c|}
\hline Variable name & Mean & Std. Dev. & Variable Definition \\
\hline Productivity growth 2003-2006 & 0,121 & 0,366 & Growth in net value added per employee: $\log$ labour productivity 2006 - $\log$ labour productivity 2003) \\
\hline Productivity 2003 & 4,228 & 0,466 & Natural logarithm of the net value added per employee in 2003 \\
\hline Employment growth 2003-2006 & $-0,094$ & 0,414 & Growth in employment: log employment 2006 - log employment 2003 \\
\hline Fixed as set growth 2003-2006 & $-0,071$ & 0,764 & Growth in fixed assets: $\log$ fixed assets 2006 - $\log$ fixed assets 2003 \\
\hline Intramural R\&D intensity & 0,081 & 0,180 & Ratio of intramural R\&D expenditures to net value added, 2004 \\
\hline Technology acquisition intensity & 0,093 & 0,330 & Ratio of technology acquisition expenditure to net value added, 2004 \\
\hline Domestic technology transfer & 0,248 & 0,432 & Dummy indicating firms with only domestic incoming technology transfers \\
\hline International technology transfer & 0,143 & 0,350 & Dummy indicating firms with only international incoming technology transfers \\
\hline Domestic \& international technology transfer & 0,462 & 0,499 & Dummy indicating firms with both domestic \& international incoming technology transfers \\
\hline Domestic multinational firm & 0,103 & 0,304 & Dummy indicating domestic multinational firms (firms with headquarters in Belgium and at least one foreign affiliate) \\
\hline Foreign multinational firm & 0,310 & 0,463 & Dummy indicating affiliate of foreign multinational firms \\
\hline Export dummy 2002 & 0.879 & 0.326 & Dummy indicating whether a firm was exporting in 2002 \\
\hline Employment & 4,195 & 1,448 & Natural logarithm of the number of employees, 2004 \\
\hline Intramural R\&D & 8,248 & 6,146 & Natural log arithm of the intramural R\&D expenditures, 2004 \\
\hline Res ource limitations & 3,484 & 2,468 & $\begin{array}{l}\text { Importance of lack of technical personnel and financial resources as barrier to innovation, on a scale of } 0 \\
\text { (unimportant) to } 9 \text { (crucial) }\end{array}$ \\
\hline Basic R\&D orientation & 0,389 & 0,439 & $\begin{array}{l}\text { Importance of for the innovation process of information from research institutes and universities relative to } \\
\text { information from suppliers and customers. Sum of scores for research and universities divided by sum of scores of } \\
\text { suppliers snd clients }\end{array}$ \\
\hline Technology Protection & 3,364 & 3,150 & $\begin{array}{l}\text { Effectiveness of secrecy, complexity, lead time and patents as means to protect innovation and technology. Sum of } \\
\text { scores for each means of protection, with scale } 0 \text { (unimportant) to } 12 \text { (crucial) }\end{array}$ \\
\hline
\end{tabular}


Table 3: Descriptives for firms by type of technology transfers

\begin{tabular}{|c|c|c|c|c|c|c|c|c|}
\hline \multirow[b]{2}{*}{ Variables } & \multicolumn{2}{|c|}{$\begin{array}{c}\text { No technology } \\
\text { transfer } \\
(n=66) \\
\end{array}$} & \multicolumn{2}{|c|}{$\begin{array}{c}\text { Domestic } \\
\text { technology transfer } \\
(n=111)\end{array}$} & \multicolumn{2}{|c|}{$\begin{array}{c}\text { International } \\
\text { technology transfer } \\
(n=64)\end{array}$} & \multicolumn{2}{|c|}{$\begin{array}{c}\text { Domestic \& International } \\
\text { technology transfer } \\
(n=207)\end{array}$} \\
\hline & Mean & Std. Dev. & Mean & Std. Dev. & Mean & Std. Dev. & Mean & Std. Dev. \\
\hline Productivity growth 2003-2006 & 0,028 & 0,307 & 0,127 & 0,364 & 0,126 & 0,438 & 0,147 & 0,357 \\
\hline Intramural $R \& D$ intensity & 0,047 & 0,127 & 0,076 & 0,198 & 0,054 & 0,106 & 0,103 & 0,200 \\
\hline Technology acquisition intensity & 0,000 & 0,000 & 0,103 & 0,296 & 0,143 & 0,617 & 0,101 & 0,263 \\
\hline Foreign multinational firm & 0,227 & 0,422 & 0,081 & 0,274 & 0,500 & 0,504 & 0,401 & 0,491 \\
\hline Domestic multinational firm & 0,030 & 0,173 & 0,081 & 0,274 & 0,078 & 0,270 & 0,145 & 0,353 \\
\hline Export dummy 2002 & 0,742 & 0,441 & 0,811 & 0,393 & 0,953 & 0,213 & 0,937 & 0,243 \\
\hline Employment & 3,371 & 1,045 & 3,725 & 0,968 & 4,184 & 1,370 & 4,714 & 1,589 \\
\hline Resource limitations & 2,409 & 2,637 & 3,757 & 2,566 & 3,219 & 2,523 & 3,763 & 2,246 \\
\hline Basic $R \& D$ orientation & 0,150 & 0,268 & 0,348 & 0,460 & 0,323 & 0,350 & 0,507 & 0,458 \\
\hline Technology protection & 1,394 & 2,246 & 2,766 & 2,565 & 3,453 & 3,091 & 4,285 & 3,349 \\
\hline
\end{tabular}


Table 4: Firm Characteristics and the Adoption of Technology Transfer Strategies:

Results of the Multinomial Probit Model

\begin{tabular}{|c|c|c|c|}
\hline & \multicolumn{3}{|c|}{ Technology transfers } \\
\hline & Only domes tic & Only international & Domestic \& international \\
\hline \multirow[t]{2}{*}{ Export dummy 2002} & 0.279 & 0.882 & 0.773 \\
\hline & {$[0.324]$} & {$[0.426]^{* *}$} & {$[0.344]^{* *}$} \\
\hline \multirow[t]{2}{*}{ Employment } & 0.247 & 0.265 & 0.418 \\
\hline & {$[0.118]^{* *}$} & {$[0.139] *$} & {$[0.117]^{* * *}$} \\
\hline \multirow[t]{2}{*}{ Foreign multinational firm } & -0.938 & 0.667 & 0.385 \\
\hline & {$[0.338]^{* * *}$} & {$[0.326]^{* *}$} & {$[0.287]$} \\
\hline \multirow[t]{2}{*}{ Domestic multinational firm } & -0.058 & 0.344 & 0.204 \\
\hline & {$[0.559]$} & {$[0.577]$} & {$[0.537]$} \\
\hline \multirow[t]{2}{*}{ Intramural R\&D } & 0.008 & 0.011 & 0.070 \\
\hline & {$[0.022]$} & {$[0.024]$} & {$[0.022]^{* * *}$} \\
\hline \multirow[t]{2}{*}{ Resource limitations } & 0.100 & 0.057 & 0.137 \\
\hline & {$[0.051]^{*}$} & {$[0.055]$} & {$[0.051]^{* * *}$} \\
\hline \multirow[t]{2}{*}{ Basic R\&D orientation } & 0.847 & 0.649 & 1.204 \\
\hline & {$[0.339]^{* *}$} & {$[0.358]^{*}$} & {$[0.329]^{* * *}$} \\
\hline \multirow{2}{*}{ Technology Protection } & 0.076 & 0.109 & 0.121 \\
\hline & {$[0.048]$} & {$[0.049]^{* *}$} & {$[0.047]^{* * *}$} \\
\hline \multicolumn{4}{|l|}{ Industry dummies: } \\
\hline \multirow{2}{*}{ Food. drinks and tobacco } & 0.380 & -0.217 & -0.065 \\
\hline & {$[0.519]$} & {$[0.588]$} & {$[0.506]$} \\
\hline \multirow[t]{2}{*}{ Textiles and leather } & 0.259 & 0.292 & 1.187 \\
\hline & {$[0.730]$} & {$[0.751]$} & {$[0.650]^{*}$} \\
\hline \multirow[t]{2}{*}{ Paper. printing and publishing } & 0.819 & 0.279 & 0.262 \\
\hline & {$[0.589]$} & [0.649] & {$[0.630]$} \\
\hline \multirow[t]{2}{*}{ Petroleum. chemicals and pharmaceuticals } & -0.785 & -0.307 & -0.173 \\
\hline & {$[0.792]$} & [0.635] & [0.547] \\
\hline \multirow[t]{2}{*}{ Rubber and plastics } & 0.398 & 0.995 & 0.640 \\
\hline & [0.915] & [0.835] & {$[0.846]$} \\
\hline \multirow[t]{2}{*}{ Non-metal mineral products } & 1.214 & 0.940 & 0.544 \\
\hline & [0.829] & {$[0.851]$} & {$[0.798]$} \\
\hline \multirow[t]{2}{*}{ Metals } & 0.047 & -0.039 & -0.153 \\
\hline & {$[0.523]$} & {$[0.533]$} & {$[0.508]$} \\
\hline \multirow[t]{2}{*}{ Machinery } & 0.108 & -0.458 & -0.570 \\
\hline & {$[0.546]$} & {$[0.581]$} & {$[0.566]$} \\
\hline \multirow[t]{2}{*}{ Electrical equipment } & 0.505 & 0.359 & -0.026 \\
\hline & {$[0.663]$} & {$[0.651]$} & {$[0.646]$} \\
\hline \multirow[t]{2}{*}{ Cars and transport equpment } & 0.577 & -0.016 & -0.838 \\
\hline & {$[0.678]$} & {$[0.650]$} & {$[0.637]$} \\
\hline \multirow[t]{2}{*}{ Construction. transport and telecommunication } & 0.439 & -0.589 & -0.319 \\
\hline & {$[0.483]$} & {$[0.615]$} & [0.490] \\
\hline \multirow[t]{2}{*}{ IT. financial and technical services } & 0.417 & -0.139 & -0.077 \\
\hline & {$[0.482]$} & {$[0.472]$} & {$[0.441]$} \\
\hline \multirow[t]{2}{*}{ Health and social services } & 0.530 & -0.405 & -0.187 \\
\hline & {$[0.494]$} & {$[0.653]$} & {$[0.507]$} \\
\hline Constant & -1.642 & -2.629 & -3.220 \\
\hline & {$[0.558]^{* * *}$} & {$[0.650]^{* * *}$} & {$[0.614]^{* * *}$} \\
\hline
\end{tabular}

Observations : 448

McFadden pseudo $\mathrm{R}^{2}: 0.27$

Chi-squared : $220.82 * * *$

Notes: Firms without technology transfers are the reference category. Robust standard errors in parentheses; *, $* *, * * *$ is significant at $10 \% ; 5 \%$, and $1 \%$, respectively. Omitted industry dummy is wholesale and retail trade. 
Table 5: Technology Transfer Strategies and Productivity Growth in Belgian firms

OLS

Heckman

\begin{tabular}{|c|c|c|c|c|}
\hline & Coefficients & Robust S.E. & Coefficients & Robust S.E. \\
\hline Labor productivity 2003 & $-0.258 * * *$ & $(0.051)$ & $-0.253 * * *$ & $(0.048)$ \\
\hline Employment growth 2003-2006 & $-0.331 * * *$ & $(0.097)$ & $-0.333 * * *$ & $(0.093)$ \\
\hline Fixed asset growth 2003-2006 & $0.072 * * *$ & $(0.025)$ & $0.073 * * *$ & $(0.024)$ \\
\hline Intramural R\&D intensity & $0.182^{*}$ & $(0.094)$ & $0.177 * *$ & $(0.090)$ \\
\hline Technology acquisition intensity & $0.069^{*}$ & $(0.038)$ & $0.068^{*}$ & $(0.038)$ \\
\hline \multicolumn{5}{|l|}{ Incoming technology transfers: } \\
\hline - Only domestic & 0.033 & $(0.045)$ & 0.039 & $(0.045)$ \\
\hline - Only international & $0.100^{*}$ & $(0.056)$ & $0.109 * *$ & $(0.054)$ \\
\hline - Both domestic and international & $0.136^{* * *}$ & $(0.043)$ & $0.150 * * *$ & $(0.045)$ \\
\hline Foreign multinational firm & 0.020 & $(0.039)$ & 0.048 & $(0.052)$ \\
\hline Domestic multinational firm & -0.076 & $(0.059)$ & -0.019 & $(0.082)$ \\
\hline \multicolumn{5}{|l|}{ Industry dummies } \\
\hline Food, drink and tobacco & 0.089 & $(0.066)$ & $0.152 *$ & $(0.091)$ \\
\hline Textile sector & $-0.132 * *$ & $(0.062)$ & -0.090 & $(0.075)$ \\
\hline Paper, printing and publishing & $0.138 * *$ & $(0.067)$ & $0.173 * *$ & $(0.074)$ \\
\hline Petroleum, chemicals and pharmaceutical & 0.019 & $(0.094)$ & 0.062 & $(0.109)$ \\
\hline Rubber and plastic & -0.065 & $(0.086)$ & 0.004 & $(0.107)$ \\
\hline Manufacturing of non metal mineral products & 0.111 & $(0.071)$ & $0.157 *$ & $(0.087)$ \\
\hline Metallurgy and metal products & -0.090 & $(0.062)$ & -0.040 & $(0.083)$ \\
\hline Machines and equipment & $0.129 *$ & $(0.069)$ & $0.183 * *$ & $(0.086)$ \\
\hline Electronic equipment & 0.103 & $(0.078)$ & 0.183 & $(0.118)$ \\
\hline Cars and transport & 0.007 & $(0.087)$ & 0.052 & $(0.101)$ \\
\hline Other industry & -0.066 & $(0.085)$ & -0.041 & $(0.086)$ \\
\hline Utilities and construction & -0.095 & $(0.091)$ & -0.110 & $(0.094)$ \\
\hline Transportation and telecommunication & 0.011 & $(0.071)$ & -0.001 & $(0.074)$ \\
\hline Financial institutions & 0.245 & $(0.161)$ & $0.275^{*}$ & $(0.158)$ \\
\hline IT service & -0.088 & $(0.060)$ & -0.024 & $(0.091)$ \\
\hline Other engineering services & -0.092 & $(0.077)$ & 0.010 & $(0.128)$ \\
\hline Health and social services & 0.122 & $(0.089)$ & 0.123 & $(0.088)$ \\
\hline Constant & $1.067 * * *$ & $(0.215)$ & $0.908 * * *$ & $(0.253)$ \\
\hline Observations & 448 & & 448 & \\
\hline R-squared & 0,33 & & 0,33 & \\
\hline Wald chi-square & $175,89 * * *$ & & $151,37 * * *$ & \\
\hline Heckman Correction: $\rho$ & & & 0,358 & 0,330 \\
\hline
\end{tabular}

Notes: Robust standard errors in parentheses; *,**,*** is significant at $10 \% ; 5 \%$, and $1 \%$, respectively. Omitted industry dummy is wholesale and retail trade. The first stage regression results of the Heckman correction for innovative firms are available in appendix B. 


\section{APPENDIX A: Correlations between variables}

Productivity growth model $(\mathrm{N}=\mathbf{4 4 8})$

$\begin{array}{lllllllllll}(1) & (2) & (3) & (4) & (5) & (6) & (7) & (8) & (9) & \text { (10) } & \text { (11) }\end{array}$

(1) Productivity growth

(2) Labour productivity 2003

1.000

(3) Employment growth

(4) Fixed assets growth

(5) Intramural R\&D intensity

$0.336 \quad 1.000$

$\begin{array}{rrr}-0.357 & 0.179 & 1.000\end{array}$

$\begin{array}{llll}0.046 & -0.007 & 0.346 & 1.000\end{array}$

$\begin{array}{lllll}0.003 & 0.120 & 0.147 & 0.055 & 1.000\end{array}$

$\begin{array}{llllll}0.066 & 0.030 & 0.051 & 0.035 & 0.044 & 1.000\end{array}$

$\begin{array}{lllllll}0.009 & -0.152 & -0.068 & -0.018 & -0.015 & 0.018 & 1.000\end{array}$

(7) Domestic technoglogy transfer

(8) International technology transfer

(8) Domestic \& international technology transfer

(10) Foreign multinational firm

$\begin{array}{llllllll}0.005 & 0.101 & -0.009 & 0.006 & -0.062 & 0.063 & -0.234 & 1.000\end{array}$

$\begin{array}{lllllllll}0.064 & 0.100 & 0.057 & 0.037 & 0.112 & 0.024 & -0.532 & -0.378 & 1.000\end{array}$

$\begin{array}{llllllllll}-0.016 & 0.267 & -0.023 & -0.098 & -0.028 & -0.074 & -0.284 & 0.167 & 0.182 & 1.000\end{array}$

(11) Domestic multinational firm

$\begin{array}{lllllllllll}-0.039 & 0.038 & -0.029 & -0.039 & 0.105 & -0.042 & -0.041 & -0.033 & 0.129 & -0.227 & 1.000\end{array}$

Technology transfer model $(\mathrm{N}=448)$

\begin{tabular}{|c|c|c|c|c|c|c|c|c|c|c|c|c|}
\hline & $(1)$ & $(2)$ & (3) & (4) & $(5)$ & (6) & $(7)$ & $(8)$ & $(9)$ & $(10)$ & $(11)$ & $(12)$ \\
\hline (1) No technology transfer & 1.000 & & & & & & & & & & & \\
\hline (2) Domestic technology transfer & -0.239 & 1.000 & & & & & & & & & & \\
\hline (3) International technology tranfer & -0.170 & -0.234 & 1.000 & & & & & & & & & \\
\hline (4) Domestic \& international technology transfer & -0.385 & -0.532 & -0.378 & 1.000 & & & & & & & & \\
\hline (5) Export dummy 2002 & -0.175 & -0.121 & 0.092 & 0.164 & 1.000 & & & & & & & \\
\hline (6) Foreign Multinational firm & -0.075 & -0.284 & 0.167 & 0.182 & 0.174 & 1.000 & & & & & & \\
\hline (7) Domestic Multinational firm & -0.099 & -0.041 & -0.033 & 0.129 & 0.103 & -0.227 & 1.000 & & & & & \\
\hline (8) Employment & -0.237 & -0.187 & -0.003 & 0.332 & 0.146 & 0.338 & 0.254 & 1.000 & & & & \\
\hline (9) Intramural R\&D & -0.269 & -0.143 & -0.070 & 0.364 & 0.152 & 0.082 & 0.295 & 0.450 & 1.000 & & & \\
\hline (10) Resource limitations & -0.181 & 0.063 & -0.044 & 0.105 & 0.006 & -0.093 & 0.044 & -0.030 & 0.073 & 1.000 & & \\
\hline (11) Basic R\&D orientation & -0.226 & -0.054 & -0.061 & 0.251 & 0.028 & 0.040 & 0.088 & 0.202 & 0.287 & 0.170 & 1.000 & \\
\hline (12) Technology protection & -0.260 & -0.109 & 0.012 & 0.271 & 0.171 & 0.146 & 0.188 & 0.295 & 0.383 & 0.178 & 0.287 & 1.000 \\
\hline
\end{tabular}




\section{APPENDIX B: First Stage Results for the Heckman Selection Model}

\begin{tabular}{lll} 
& Coefficients & Robust S.E. \\
\hline Number of employees in 2002 & $1.528 * * *$ & $(4.325)$ \\
Numbers of employees in 2002 squared & $-0.083^{* * *}$ & $(0.025)$ \\
Age of the firm & -5.770 & $(8.371)$ \\
Age of the firm squared & 0.082 & $(0.113)$ \\
No demand for innovations & $-0.352^{* * *}$ & $(0.045)$ \\
Foreign multinational firm & $0.266^{* *}$ & $(0.123)$ \\
Domestic multinational firm & $1.004 * * *$ & $(0.246)$ \\
Industry dummies and constant & & included \\
\hline Observations & 939 & \\
Pseudo R-squared & 0,215 & \\
Wald chi squared & $279.92 * * *$ &
\end{tabular}

Notes: Robust standard errors in parentheses; *,**,*** is significant at $10 \% ; 5 \%$ and $1 \%$, respectively. Omitted industry dummy is wholesale and retail trade. The variables employees, age, age squared are rescaled (divided by 1000); employees squared is divided by one million. 


\section{Endnotes}

${ }^{\mathrm{i}}$ The presence of MNE affiliates in industrialized countries in particular may subsequently lead to local knowledge spillovers and productivity benefits for local firms (Görg and Strobl, 2001; Kugler, 2006; Van Pottelsberghe and Lichtenberg, 2001; Haskel et al, 2007; Crespi et al, 2007)

${ }^{\text {ii }}$ The literature on technology licensing is a partial exception but has primarily focused on licensing to local firms in developing and newly industrializing countries (Basant and Fikkert, 1996; Braga and Wilmore, 1991; Branstetter and Chen, 2006).

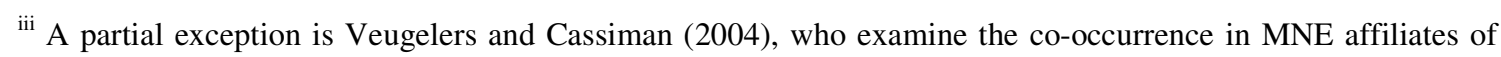
outgoing transfers to the host economy and incoming transfers from abroad.

${ }^{\text {iv }}$ From the viewpoint of the receiving firm, (incoming) technology transfers can be equated to technology sourcing. We will use these terms interchangeably in the remainder of this paper.

${ }^{v}$ Recent work by Criscuolo (2009) furthermore suggests that such reverse technology transfers may subsequently generate spillovers to other firms in the home country.

${ }^{\text {vi }}$ Higher depreciation rates lead to an upward bias of the estimate on the rate of return.

${ }^{\text {vii }}$ Klette and Johansson (1998) derive this specification based on an accumulation process for R\&D capital that allows for a positive complementarity between already acquired knowledge and current R\&D in the generation of new knowledge.

${ }^{\text {viii }}$ We empirically examine whether the restriction of analysis to 448 firms introduces selection bias in section 5 .

${ }^{\text {ix }}$ Hence the transfers are a broad measure of knowledge flows and are a mixture of knowledge transfers that may be involuntary and due to spillovers (informal channels, personnel transfer) and technology acquisition through market transactions (e.g. licensing purchases). Blalock and Gertler (2008) argue for such a broader definition of technology transfers that is not limited to the spillovers but includes purposeful transfers.

${ }^{\mathrm{x}}$ The data did not allow us to further distinguish these exclusive classes of sourcing strategies into intra-group and extra-group transfers for MNEs or domestic firm groupings. The information available does distinguish between the European and non-European origins of technology transfer. We discuss this feature in the extensions.

${ }^{\mathrm{xi}}$ An alternative specification that would interact the external $R \& D$ variable with the technology transfer dummies to bring in proxy for the scale of transfer activities is less feasible because of the differential definitions of external R\&D and technology transfer, the lack of information concerning the relative values of investments on the three strategies, and the multicollinearity created in this specification. 
xii Separating the effectiveness of legal patent from other forms of protection showed no further significance of the use of legal protection mechanisms.

xiii Due to the sparseness or absence of specific technology sourcing strategies in some industries, we had to aggregate 4 industries with few firm observations.

${ }^{\text {xiv }}$ This may indicate rationalization efforts during the period, but it is also partly due to the presence of a number of firms in the sample reporting particularly strong declines in employment and fixed assets.

${ }^{x v}$ Although a multinomial probit model is computationally demanding, it is preferred over a multinomial logit model as it does not rely on the assumption of independence of irrelevant alternatives (IIA), a key restriction of the multinomial logit model.

${ }^{x v i}$ The latter coefficient for capital is rather low but not inconsistent with prior work. Verormelingen and Konings (2009) report similar low elasticities of 0.088 in several specifications for a much larger set of Belgian firms covering a similarly broad range of industries. Partly this will be due to the use of data on the book value of capital (in the absence of fixed capital investment series data), which may imply that the capital stock is imprecisely estimated. Also, our analysis will to an extent suffer from the well-known property of productivity models that differencing can increase measurement error in regressors, which may lead to estimation biases in the coefficients of less accurately measured variables ((Haskell et al, 2007, Hall et al, 2010).

${ }^{\text {xvii }}$ Lokshin et al (2008) report coefficients for intramural and external $R \& D$ intensities close to 0.3 and 0.8 , respectively. A coefficient of around 0.18 for intramural R\&D intensity suggests that hundred Euros spent on R\&D increases value added by around 18 Euros.

xviii The intramural R\&D intensity of domestic MNEs in the sample is on average twice as large as the R\&D intensity of domestic firms. 